\title{
鋼材の衝撃疲労における切欠を効果についで
}

$\begin{array}{llllll}\text { 内 } & \text { 猛** } & \text { 岡 } & \text { 部 } & \text { 年** } \\ \text { 矢 野 利 } & \text { 行** } & \text { 森 } & \text { 忠 } & \text { ** }\end{array}$

\section{Effect of Notch on Impact Fatigue Strength of Mild Steels}

\author{
by
Takeshi Uchida, Nagatoshi OKaBe, Toshiyuki Yano and Tadao MoRI \\ (Heavy Apparatus Engineering Laboratory, Toshiba Corporation, Fuchu)
}

\begin{abstract}
In order to study the effect of notch on its impact fatigue strength of mild steels, low-cycle impact fatigue tests were carried out on the specimens of $0.2 \%$ carbon steel having various circumferential notches under repeated impact tensile loads. The experimental results are summarized as follows:

(1) The impact low-cycle fatigue strength $\sigma$, in the case of notched specimens, is expressed by

$$
\sigma N_{f} m^{*} T^{n *}=D^{*}
$$
\end{abstract}

where $N_{f}$ is the life of rupture, $T$ is the loading time and $m^{*}, n^{*}$ and $D^{*}$ are material constants.

(2) The relations of $m^{*}$ and $n^{*}$ with the stress concentration factor $\alpha$ are given by

where $m_{0}, a$ and $b$ are experimental constants.

$$
m^{*}=m_{0} \alpha^{a}, n^{*}=m_{0} \alpha^{b}
$$

(3) The fatigue notch factor $\beta$ is related to the stress concentration factor $\alpha$ by

where $c$ is an experimental constant.

$$
\beta=\alpha^{-c} \exp m_{0}\left(\alpha^{a}-1\right) \ln N_{f}
$$

キー・ワード : 衝撃疲労, 切欠き係数, 負荷持続時間, 低炭素鋼

(Received June 27, 1978)

\section{1 緒言}

機械構造物や機械要素は, 稼動中に生じる衝撃的な 荷重を繰返し受けて比較的長寿命で疲労破壞してしま うことがしばしばある. 平滑材としての材料の衝撃疲 労強度あるいはその疲労現象の特徴についての究明は 繰返し衝撃荷重に対する機械構造部材の疲労強度を評 価していくらえで基本的には極めて重要であり, 比較 的多くの報告がなされている。これに反し, 切欠き材 としての衝撃疲労強度あるいは切欠き効果などの特徵 についての究明は, 実用上, 極めて重要であるにもか かわらず, これらについての報告は極めて少いようで ある. そこで，本研究では， $0.2 \%$ 炭素鋼を供試材と した切欠きおよび平滑試験片に対して衝撃引張荷重の 繰返しによる低サイクル疲労試験を行い, 平滑材と切 欠き材との間に抢溥撃疲労強度の関連性あるいは 衝撃疲労現象に和ける切欠き効果について実験的に究 明した。

* 原稿受理 昭和53年 6 月 27 日

** 正会 員 東京芝浦電気(株)重電技術研究所 府中市東芝町

\section{2 実験}

\section{$2 \cdot 1$ 供試材および試験片}

本実験に供した材料は，市眅の機珹構造用炭素鋼 S20C である. その化学成分を Table I 飞示す. 試験 片は納入のままの $19 \phi$ の丸棒から Fig. 1 亿示すよう な形状寸法に機械加工したのち真空加熱炉中で Table II のよらな真空焼なむしを施した。真空焼なるし後 の平滑試騟片の静的引張りによる機械的性質を Table II に示す. 各切欠き試験片の切欠きは，いずれる環 状溝切欠きであり，切欠き底の径を平滑試験片の径に 合せている，切欠き試験片 [A]，[C]はU形溝，切 欠き試験片〔B]は半円溝, 切欠き試験片〔D]は $60^{\circ}$ のV形溝である. 各切欠き部の応力集中係数 $\alpha$ は (1)式のような近似計算式を用いて求めると, Table

Table I. Chemical composition (\%).

\begin{tabular}{c|c|c|c|c}
\hline $\mathrm{C}$ & $\mathrm{Si}$ & $\mathrm{Mn}$ & $\mathrm{P}$ & $\mathrm{S}$ \\
\hline 0.20 & 0.21 & 0.52 & 0.018 & 0.013 \\
\hline
\end{tabular}




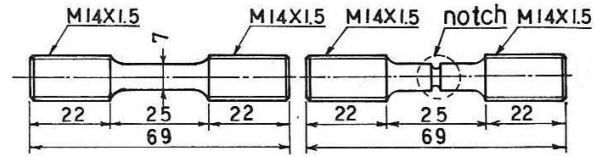

Smoothed specimen Notchedspecimen

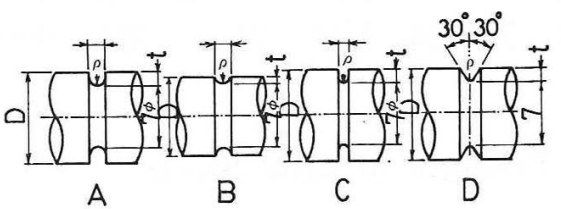

Notch detail of specimens

\begin{tabular}{|c|c|c|c|c|}
\cline { 2 - 5 } \multicolumn{1}{c|}{} & $A$ & $B$ & $C$ & $D$ \\
\hline$D^{\phi}$ & 10 & 8.75 & 10 & 10.5 \\
\hline$\rho$ & 1 & 0.875 & 0.5 & 0.23 \\
\hline$t$ & 1.5 & 0.875 & 1.5 & 1.75 \\
\hline
\end{tabular}

Fig. 1. Shape and dimension of specimens.

Table II. Mechanical properties and heat treatment.

\begin{tabular}{c|c|c|c|c}
\hline $\begin{array}{c}\text { Yielding } \\
\text { stress } \\
\sigma_{y}\left(\mathrm{~kg} / \mathrm{mm}^{2}\right)\end{array}$ & $\begin{array}{c}\text { Tensile } \\
\text { strength } \\
\sigma_{B}\left(\mathrm{~kg} / \mathrm{mm}^{2}\right)\end{array}$ & $\begin{array}{c}\text { Elongation } \\
\delta(\%)\end{array}$ & $\begin{array}{c}\text { Reduction } \\
\psi(\%)\end{array}$ & $\begin{array}{c}\text { Heat } \\
\text { treatment }\end{array}$ \\
\hline 31.5 & 44.6 & 32.5 & 69.0 & $\begin{array}{c}900^{\circ} \mathrm{C} \times 30 \mathrm{~min} \\
\text { Vaccume } \\
\text { annealing }\end{array}$ \\
\hline
\end{tabular}

Table III. Stress concentration factor $\alpha$.

\begin{tabular}{l|c|c|c|c}
\hline \multicolumn{1}{c|}{ Specimen } & A & B & C & D \\
\hline by formula (1) & 1.87 & 2.00 & 2.65 & 3.78 \\
by Neuber's theory & 1.55 & 2.17 & 2.90 & 4.03 \\
by Peterson's theory & 2.01 & 2.06 & 2.65 & 3.73 \\
\hline
\end{tabular}

III のような值になる。

$$
\begin{aligned}
\alpha & =f(\theta) k_{0} / \sqrt{\rho}=f(\theta) \sqrt{a / \rho} \\
f(\theta) & =\frac{1-\exp \{-0.90 \sqrt{B / t}(\pi-2 \theta)\}}{1-\exp \{-0.90 \pi \sqrt{B / t}\}}
\end{aligned}
$$

ここで, $f(\theta)$ は切欠き部の角度係数, $k_{0}$ は $\theta=0$ のときの荷重モードによって決まる係数で, 引張荷重 モードのとき $k_{0}=\sqrt{a}$ である. なお， $2 \theta ， 2 B, t, 2 a$ は, Fig. 2 に示すように, 切欠きの角度, 試験片の外 径，切欠き深さおよび切欠き底の径である。

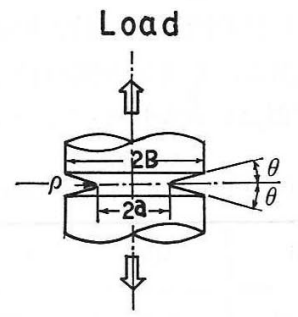

Fig. 2. Shape of notched specimens.

\section{$2 \cdot 2$ 衝撃疲労試験装置および実験方法}

衝撃疲学試験には, Fig. 3 に示すよらに, 円筒と丸 棒との縦衝撃現象を利用した繰返し衝撃引張荷重装㯰 を用いた. 1 回の衝撃によって, 試験片には Fig.4 に亦すような矩形波状の引張応力パルスが負荷される。 衝撃負荷応力の大きさ $\sigma$ 拈よびその持続時間 $T$ は円筒 の落下高さ $h$ 括上び円筒の長さ $l$ をもとに次式で求め られる。

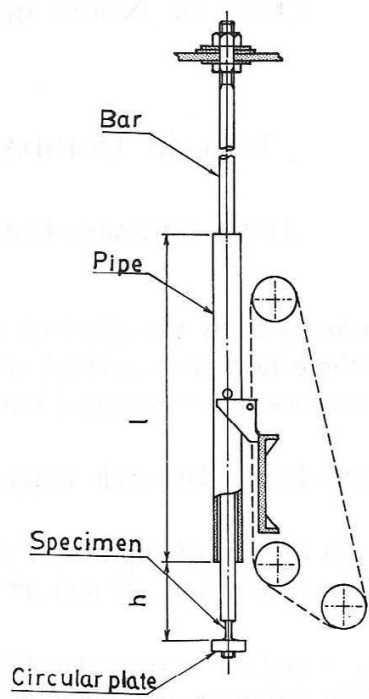

Fig. 3. Experimental apparatus.
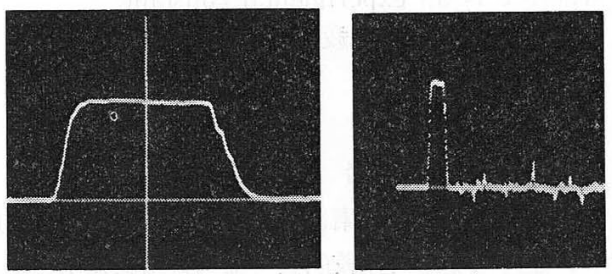

Fig. 4. An example of measured stress wave.

$$
\begin{gathered}
\sigma=\frac{A_{1} A_{3}}{A_{0}\left(A_{1}+A_{3}\right)} \sqrt{E r_{V}} \sqrt{2 h} \\
T=\frac{2 l}{C}
\end{gathered}
$$

ここで, $A_{0}, A_{1}, A_{3}$ は試験片, 円筒, 吊り丸棒の各 横断面積で， $E ， \gamma, C$ は鋼のヤング率，比重量およ び縦弾性波の伝ぱ速度である。

Fig. 4 に示す実測応力波形は，吊り丸棒のロードセ ル部に生じる衝撃ひずみを，同一円周上に $90^{\circ}$ 間隔に 貼付してシリーズに接続した 4 枚のひずみゲージ（型 式：KFC-1-C1-11）で検出し衝撃ひずみ計を介して デジタルメモリオシロスコープ（型式；NICOLET 1090A）に記録したものである.

実験方法としては，大気中，室温（20２5ㅇ）にて 各試験片に対して, 円筒の落下高さ一定で衝撃引張荷 
重を試験片が破断するまで繰返した。この繰返し数を 衝撃疲労破壊寿命 $N_{f}$ とし, 衝撃負荷応力 $\sigma(\mathrm{kg} /$ $\left.\mathrm{mm}^{2}\right)$ としては, 切欠き底の初期断面積を $A_{0}$ として (2)式で求めた理論值を公称応力として用い,データの 整理を行った. 一方, 負荷持続時間の条件としては, $l=1.000,2000$ 抢よび $3000 \mathrm{~mm}$ の 3 種類の円筒を用 いて, $T=400,800$ 抢よび $1200 \mu \sec$ とし負荷持続 時間の影響を調べた。

\section{3 実験結果および考察}

\section{$3 \cdot 10.2 \%$ 炭素鋼平滑材の低サイクル衝撃}

\section{疲労強度}

Fig. 5 は平滑試験片に対して衝撃引張荷重を繰返し たときの衝撃負荷応力 $\sigma$ と破壞寿命 $N_{f}$ とを両対数の 関係で示したものである. 同一持続時間の負荷条件下 では, 両者は, ほぼ直線関係があり, 次式で近似でき る.

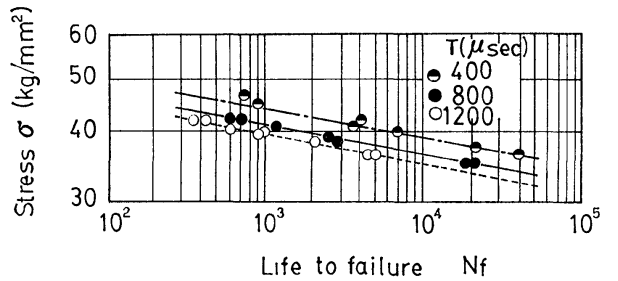

Fig. 5. $S-N$ curves for smoothed specimens.

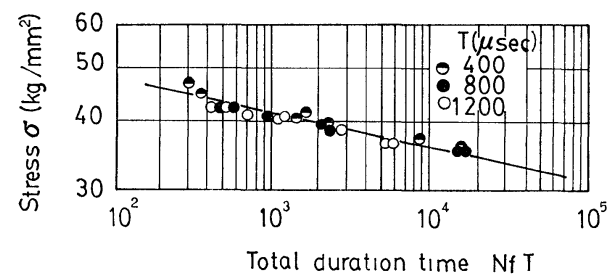

Fig. 6. Relation between stress $\sigma$ and total duration time $N_{f} T$ for smoothed specimens.

$$
\sigma N_{f} m_{0}=C_{0}
$$

また，衝撃負荷の応力が等しくても，負荷持続時間が 長くなる汪ど，破壞寿命は短くなることがわかる。

そこで破壞寿命と負荷持続時間との積 $N_{f} \cdot T$ を破 壤までの累積負荷時間とし， $\sigma$ と $\left(N_{f} T\right)$ とを両対数 の関係で示すと Fig. 6 のようになり，両者は，ほぼ 直線関係があるので，次式で近似できる.

$$
\sigma\left(N_{f} \cdot T\right)^{m_{0}}=D_{0}
$$

な怙，(5)，(6)式に和ける指数 $m_{0}$ 扩よび強度定数 $C_{0}$, $D_{0}$ を Table IV に示す.

Table IV. Values of strength constant $D_{0}$ and constant $m_{0}$ for smoothed specimen.

\begin{tabular}{c|c}
\hline$D_{0}$ & $m_{0}$ \\
\hline $41.70\left(\mathrm{~kg} / \mathrm{mm}^{2}\right)$ & 006263 \\
\hline
\end{tabular}

$0.2 \%$ 炭素鋼の平滑材にみられる前述のような衝撃 疲労特性は $0.01 \%, 0.097 \%, 0.36 \%, 0.47 \%$ 炭素鋼 の平滑材に执いても, 茶谷, 中原, 中沢等の研究で明 らかにされている.

\section{$3 \cdot 2 \quad 0.2 \%$ 炭素鋼切欠き材の低サイクル 衝撃疲労} 強度

Fig. 7 は, 各切欠き試験片 $[A],[B],[C],[D]$ に対して衝撃引張荷重を繰返したときの衝撃負荷芯力 $\sigma$ と破壞寿命 $N_{f}$ とを両対数の関係で示したものであ る.いずれの切欠き材に执いても平滑材の場合同様, 同一持続時間の負荷条件下では, 両者はほぼ直線関係 があり，次式で近似できる。

$$
\sigma N_{f}^{m *}=C^{*}
$$

なお，指数 $m^{*}$ および強度定数 $C^{*}$ を Table $\mathrm{V}$ 亿示 す. $C_{1} *, C_{2}{ }^{*}, C_{3} *$ はそれぞれ，負荷持続時間が $T=$ $400,800,1200 \mu \mathrm{sec}$ の場合の值を示す. ここで, 注
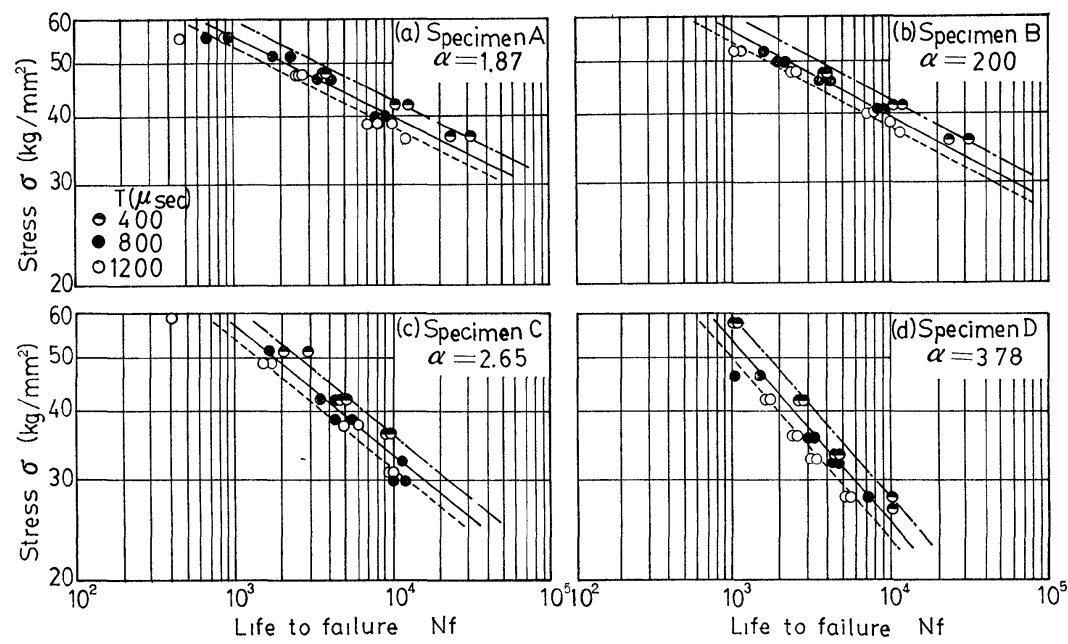

Fig. 7. $S-N$ curves for notched specimens. 
Table V (a). Values of constant $m^{*}$ for notched specimens.

\begin{tabular}{c|c|c|c|c}
\hline Specimen & A & B & C & D \\
\hline $\mathrm{m} *$ & 0.1439 & 0.1538 & 0.2306 & 0.3269 \\
\hline
\end{tabular}

Table V (b). Values of strength constant $C^{*}$ for notched specimens.

\begin{tabular}{c|c|c|c|c}
\hline Specimens & A & B & C & D \\
\hline$C_{1}{ }^{*}\left(\mathrm{~kg} / \mathrm{mm}^{2}\right)$ & 161.5 & 175.8 & 305.3 & 580.3 \\
$C_{2}{ }^{*}\left(\mathrm{~kg} / \mathrm{mm}^{2}\right)$ & 150.9 & 164.9 & 279.3 & 515.7 \\
$C_{3}{ }^{*}\left(\mathrm{~kg} / \mathrm{mm}^{2}\right)$ & 145.0 & 158.3 & 265.1 & 481.3 \\
\hline
\end{tabular}

目すべきことは, 指数 $m *$ および切欠き材の衝撃疲労 強度に及ぼす負荷持続時間の影響が，いずれる各切欠 き材によって大いに異ることである。

そこで，各切欠き材における(7)式の強度定数 $C^{*}$ と 負荷持続時間 $T$ との関係を両対数の 関係で示すと, Fig. 8 のように両者は核ぼ直線関係があるので, 次式 で近似できる。

$$
C^{*} T^{n *}=D^{*}
$$

なお，指数 $n$ *は Table VI に示すような值となり， この指数 $n *$ もまた各切欠き材によって大いに異るこ とが明らかに認められる.

そこで, これらの指数 $m^{*}$ および $n^{*}$ と切欠き部の 応力集中係数 $\alpha$ との関係を両対数の関係で示すと, Fig. 9 のようになり, 両指数とも $\alpha$ の增大とともに直 線的に増大する傾向があるので，両指数はそれぞれ，

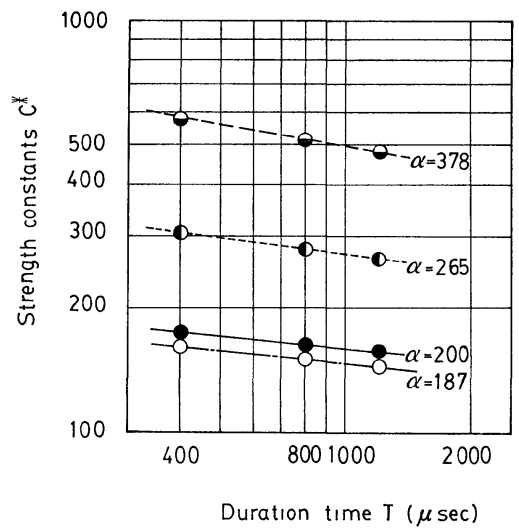

Fig. 8. Relation between strength constants $C^{*}$ and duration time $T$.

Table VI. Values of constant $n^{*}$ for notched specimens.

\begin{tabular}{c|c|c|c|c}
\hline Specimens & $\mathrm{A}$ & $\mathrm{B}$ & $\mathrm{C}$ & $\mathrm{D}$ \\
\hline$n *$ & 009838 & 009251 & 0.1283 & 0.1702 \\
\hline
\end{tabular}

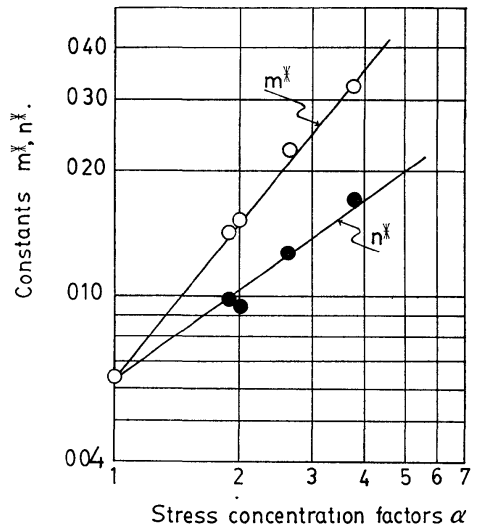

Fig. 9. Relation between stress concentration factors $\alpha$ and constants $m^{*}, n^{*}$.

$\alpha$ との関係を次式で近似できる.

$$
\begin{gathered}
m^{*}=m_{0} \alpha^{a} \\
n^{*}=m_{0} \alpha^{b}
\end{gathered}
$$

な和，(9)，(10)式汸拈ける指数 $a ， b$ は， $\alpha=1$ のとき， $m^{*}=n^{*}=m_{0}$ となるように定めた值で, Table VII に 示すような值になる。一方, 切欠き材の場合の(7)式に 括汗る強度定数 $C^{*}$ と切欠き部の応力集中係数 $\alpha$ との 関係を明らかにするため, 平滑材の場合の(5)式に和け る強度定数 $C_{0}$ に対する強度定数 $C^{*}$ の比; $C^{*} / C_{0}$ を 求め, $\left(C^{*} / C_{0}\right)$ と $\alpha$ との関係を両対数の関係で示すと, Fig. 10 のようになり, 切久き材の場合の強度定数 $C^{*}$ は切欠き部の応力集中が大きくなるほど，増大する傾 向があり，次式でよく近似できる.

$$
C^{*}=C_{0} \alpha^{c}
$$

な扮，指数Cは Table VII に示す.

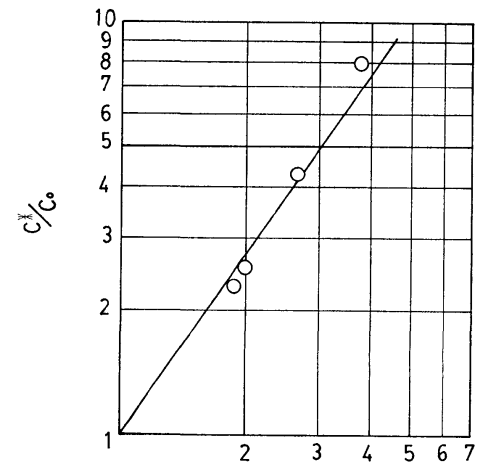

Stress concentration factors $\alpha$

Fig. 10. Relation between stress concentration factors $\alpha$ and $C^{*} / C_{0}$.

Table VII. Values of constant a, b, c.

\begin{tabular}{c|c|c}
\hline $\mathrm{a}$ & $\mathrm{b}$ & $\mathrm{c}$ \\
\hline 1.258 & 0.7214 & 1.616 \\
\hline
\end{tabular}


次いで，(7)，(8)式よりC*を消去して整理すると， 切欠き材の衝撃疲労に拈ける衝撃負荷応力 $\sigma$ 之破壊寿 命 $N_{f}$ との関係は次式のようになり,

$$
\sigma N_{f}{ }^{m *} T^{n *}=D^{*}
$$

平滑材の衝撃疲労の場合同様, 負荷持続時間 $T$ が衝撃 疲労強度に効くことがわかる。しかしながら，その効 き方は Fig. 11 に示す $\left(n^{*} / m^{*}\right)$ と $\alpha$ との関係からわ かるように，切欠き部の応力集中が大きくなるほど， 減少する傾向がある.

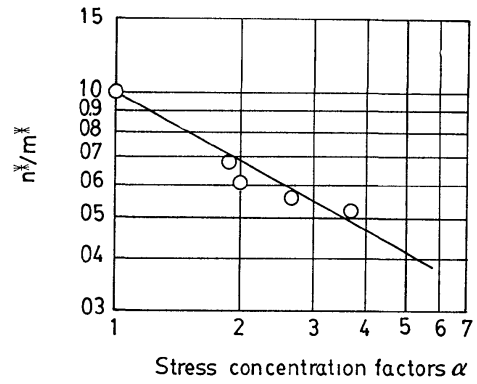

Fig. 11. Relation between stress concentration factors $\alpha$ and $n^{*} / m^{*}$.

\section{$3 \cdot 3 \quad 0.2 \%$ 炭素鋼の衝撃疲労現象における 切欠き 効果}

Fig. 12 は負荷持続時間が $T=800 \mu \mathrm{sec}$ の場合の平 滑材および各切欠き材の衝撃疲労における衝撃負荷応 力 $\sigma$ と破壊寿命 $N_{f}$ との関係の近似直線 〔近似式 : (5) あるいは(7)式]を示したものである．低寿命領域では， 切欠き材の方が平滑材よりその衝撃疲労強度は高いけ れども，高寿命領域に移るに従って切欠き材と平滑材 との衝撃疲労強度は，応力集中の大きい切欠き材の方 から次第に逆転して行く．各切欠き材の間での衝撃疲 労強度も, 切欠き部の応力集中の大きいものほぼ, 低 寿命領域では高応力レベルにあり，高寿命領域に移る

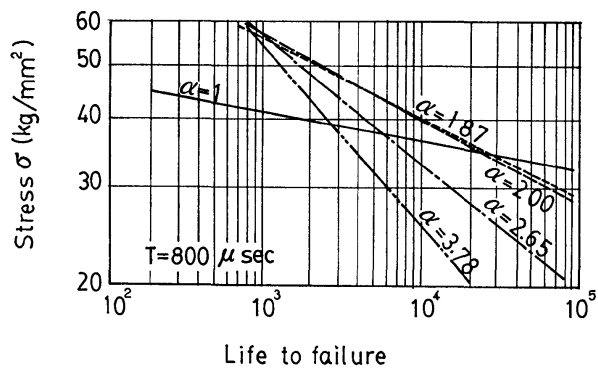

Fig. 12. Comparison of $S-N$ curves for smoothed and notched specimens.

につれて逆転し，低応力レベルになる．これらの現象 は程度の差こそあれ，一般の疲労の場合においても認 められることである。

以上のような切欠き材の衝撃疲労現象を以下のよう な解釈で説明する．低寿命領域で疲労破壊するような 大さな公称衝撃負荷応力に対しては, 弾性解析による 環状切欠き底近傍の応力分布が供試材の動的降伏強度 $\sigma_{d y}$ を越える範囲には，Fig. 13 (a)のように塑性領域 が形成される. その塑性領域内での軸方向の真の引張 応力 $\sigma_{\text {true }}$ は 3 軸性による塑性拘束の影響で切欠き底 から半径方向へ向らほど, 次式のように増大し, 弾塑 性境界で最大となる。

$$
\sigma_{\text {true }}=\sigma_{d y}[1+\ln (1+r / \rho)]
$$

衝撃負荷の解放後, 弾性領域の弾性復元により塑性 領域内には太破線で示されるような圧縮残留応力が生 じる.したがって，つぎの衝撃負荷による応力分布は 細破線で示すようになり，切欠き先端での応力は公称 衝撃負荷応力の值より低くなるところが出てくる. そ れゆえ，応力集中係数 $\alpha$ の大きいものほど，同一值の 公称衝撃負荷応力に対する切欠き底での疲労き裂発生 寿命は延び，それだけ破壤寿命 $N_{f}$ が長くなるものと 考学られよう．これに反し，高寿命領域で疲労破壊す

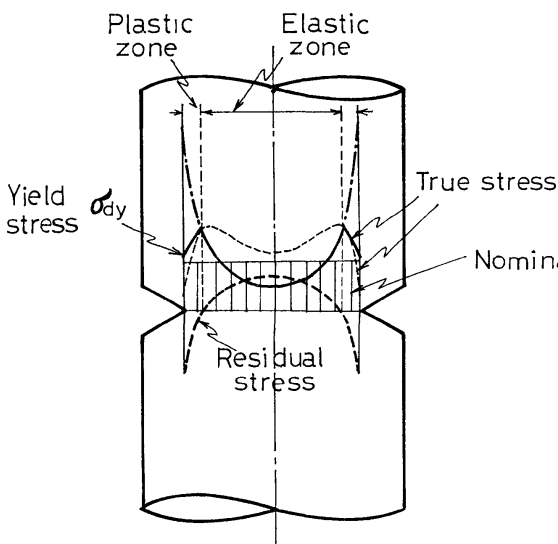

(a)

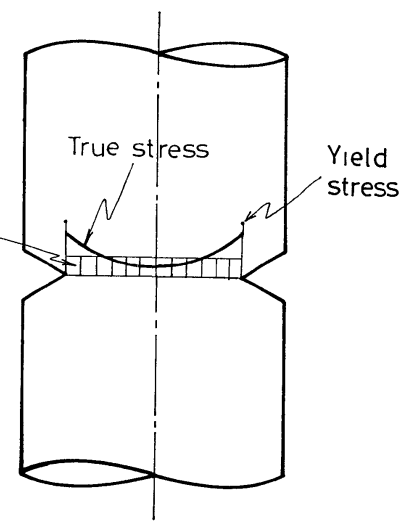

(b)

Fig. 13. Schematic presentation of stress distribution. 
るような公称衝撃負荷応力に対しては, 弾性解析によ る応力分布が切欠き先端でも供試材の動的降伏強度 $\sigma_{d y}$ をFig. 13 (b)の上うに越光ず, 衝撃負荷の解放後 飞残留応力が生じないか, あるいは, 動的降伏强度 $\sigma_{d y}$ をかずかに越すが衝撃負荷の解放後に生じる圧縮 残留応力が小さなため, 次の衝撃負荷による真の応力 分布が切欠き先端で公称衝撃負荷応力の值より大きく なる. したがって応力集中係数 $\alpha$ のきいものほど， 切欠き底での疲労き裂発生寿命は短くなり，それだけ 破壊寿命 $N_{f}$ が短くなると考学る.

切欠き材と平滑材との疲労破壊強度が逆転するよう な寿命領域では, 衝撃負荷の解放後に切欠き先端の塑 性領域に生じている圧縮残留応力に次の衝撃負荷応力 が重畳したときの切欠き先端の真の応力が公称衝撃負 荷応力の值とほぼ等しいか, わずかに低い程度になり, 切欠き底での疲労き裂発生寿命が平滑材の疲労き裂発 生寿命と湾济一致するか, わずかに長いのではないか と考える.

次いで下記のように一般に定義される切欠き係数 $\beta$ を用いて $0.2 \%$ 炭素鋼の衝撃疲労現象に打壮る切欠き 効果の特徵について考学ることにする.

切欠き係数 ; $\beta=\frac{\text { 平滑材の疲労強度 }}{\text { 切欠き材の疲労強度 }}$

いま，(6)式と(12)式から切欠き俰数及の式を導くと， 次式のようになる.

$$
\beta=\left(D_{0} / D^{*}\right) \exp \left\{\left(m^{*}-m_{0}\right) \ln N_{f}+\left(n^{*}-m_{0}\right) \ln T\right\}
$$

ところが，(5)，(6)式より $C_{0} T^{m_{0}}=D_{0} ，(8)$ 式より $C^{*}$ $T^{n *}=D^{*}$ ，(11)式より $C^{*}=C_{0} \alpha^{c}$ であり，また，(9)，(10) 式より $m^{*}=m_{0} \alpha^{a}, n^{*}=m_{0} \alpha^{b}$ であるので, これらの 式から $C_{0}, C^{*}, m^{*}, n^{*}$ を消去して整理すると， $D_{0} /$ $D^{*}$ は次式で与兄られる.

$$
D_{0} / D^{*}=\alpha^{-c} \exp m_{0}\left(1-\alpha^{b}\right) \ln T
$$

したがって，(13)式に(14)式を代入して整理すると，(13)式 の切欠き係数 $\beta$ は次式のようになり，

$$
\beta=\alpha^{-c} \exp m_{0}\left(\alpha^{\alpha}-1\right) \ln N_{f}
$$

切欠き部の応力集中係数 $\alpha$ と破壞寿命 $N_{f}$ との関数と して与えられる.この上らに衝撃疲労に掓る切欠き 効果を任意の破壞寿命に怙沙る切欠き係数 $\beta$ の形で考 慮すると, 各切欠き材の 衝撃疲労に拈いて (12) 式のよ らに切久き部の応力集中係数 2 にってそれぞれ異る 負荷持続時間 $T$ の影響がなくなる.このことは，切欠 き材の衝撃疲労に括沙る切欠き效果の特徴の一つであ ると考兄る。すなわち, 平滑材としての街撃疲労強度 に対して，(6)式のように負荷持続時間 $T$ の影響を累積 負荷時間 $\left(N_{f} T\right)$ の形で考慮してお战けば, 切欠き効果 は, 西と切欠き部の応力集中係数 $\alpha$ 之破壞寿命 $N_{f}$ と によって決まり, 疲労損傷の累積による強度劣化の傾
向に影響するだけであると考えてよからう．

\section{$3 \cdot 4$ 繰返し衝撃引張荷重に対する許容応力および 疲労破壞寿命の推定}

本実験結果から明らかなように, 平滑材の衝撃疲労 強度 [(6)式]々衝撃疲労に拈ける切欠き効果 [(15)式] とを考慮することにより，0.2\%炭素鋼（焼なまし材） の場合, その切欠き部材の繰返し衝撃引張荷重（負荷

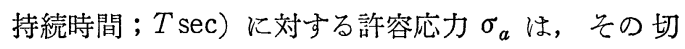
欠き部の応力集中係数 $\alpha$ を(1)式で求めると, 任意の破 壞寿命 $N_{f}$ に対して次式で推定できる.

$$
\sigma_{a}=\sigma / \beta=D_{0} / \beta\left(N_{f} T\right)^{m_{0}}=\alpha^{c} D_{0} / N_{f} m_{0} \alpha^{a} T^{m_{0}} \quad \text { (16) }
$$

また，負荷持続時間 $T \sec$ の衝撃引張負荷応力 $\sigma$ をその切欠き部材が繰返し受ける場合の破壊寿命 $N_{f}$ は次式で推定できる.

$$
N_{f}=\left[\alpha^{c / m_{0}}\left(D_{0} / \sigma\right)^{1 / m_{0}} / T\right]^{1 / \alpha a}
$$

ここで, 注目すべきことは, 平滑材の衝撃疲労強度 の近似式に和活る強度定数 $D_{0}$ が, 供試材の静的引張 強さ $\sigma_{B}$ および破断絞り $\varphi(\%)$ との間に深い関係があ ることである. 茶谷, 中沢, 中原等の研究結果では, $0.01 \%, 0.097 \%, 0.36 \% ， 0.47 \%$ 炭素鋼を中心とし た数種類の金属材料に沶いて(18)式のような関係が㭊る ことを明らかとしているが， $0.2 \%$ 炭素鋼怙よびその 他の鋼材の平滑材に対する著者等の衝撃疲労強度の研 究で得られている強度定数 $D_{0}$ の值を含めて鋼材のみ に限定した場合の強度定数 $D_{0}$ では, Fig. 14 に見ら れるように， $\sigma_{B}$ および $\varphi$ との間の関係は(19)式で近似 できるようである.

$$
\begin{gathered}
D_{0}=(0.8+0.002 \varphi) \sigma_{B} \\
D_{0}=(0.75+0.0025 \varphi) \sigma_{B}
\end{gathered}
$$

また, 指数 $m_{0}$ の值に関しても, 鋼材のみに限定し た場合, Fig.15 のように $D_{0} / \sigma_{B}$ との間に次式のよう な関係がある。

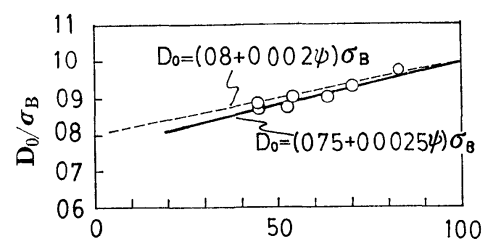

Reduction of area $\psi(\%)$

Fig. 14. Relation between reduction of area $\psi$ and $D_{0} / \sigma_{B}$.

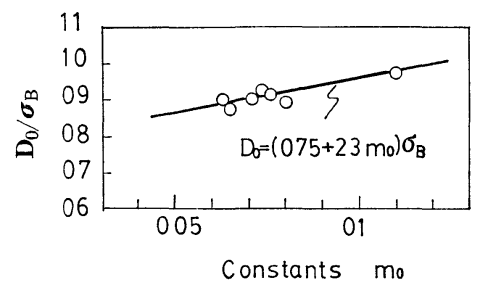

Fig. 15. Relation between constants $m_{0}$ and $D_{0} / \sigma_{B}$. 


$$
D_{0}=\left(0.75+2.3 m_{0}\right) \sigma_{B}
$$

したがって, 鋼材の引張強さ $\sigma_{B} お$ よび破断絞り $\varphi$ を基に(19)，(20)式で強度定数 $D_{0}$ 特よび指数 $m_{0}$ を求め ると, その平滑材の繰返し衝撃引張荷重に対する疲労 強度は充分推定できることがわかる。

一方, 鋼材の疲学に和ける切欠き感受性については, 村木, 石黑等の研究結果によると, 一般に(21)式で定義 される切欠き感受係数 クは引張強さ $\sigma_{B}$ に依存するが $\sigma_{B} \leqq 70 \mathrm{~kg} / \mathrm{mm}^{2}$ の鋼材では $\eta$ の值はばらつき範囲内 ではほぼ一定の值を示すようである。

$$
\eta=\frac{\beta-1}{\alpha-1}
$$

したがって，本研究で得られている切欠き部の応力 集中係数 $\alpha$ と切欠き係数 $\beta$ との関係（(15)式）も， $\sigma_{B} \leqq$ $70 \mathrm{~kg} / \mathrm{mm}^{2}$ の鋼材に対しては, 充分適用できると考 壳る。

以上のことより， $\alpha_{B} \leqq 70 \mathrm{~kg} / \mathrm{mm}^{2}$ の鋼材の場合， その切欠き部材としての繰返し衝撃引張荷重に対する 許容応力拈よび疲労破壊寿命の推定には(16)式および(17) 式を充分適用できると考える.

以上の考えのもとに，0.2\%炭素銅切欠き材（切欠 き試験片 [B], [C]）の場合について，衝撃疲労強 度と破壊寿命との関係を逆推定した直線を Fig. 16 に 示す. 実用上，充分な推定であると考える.

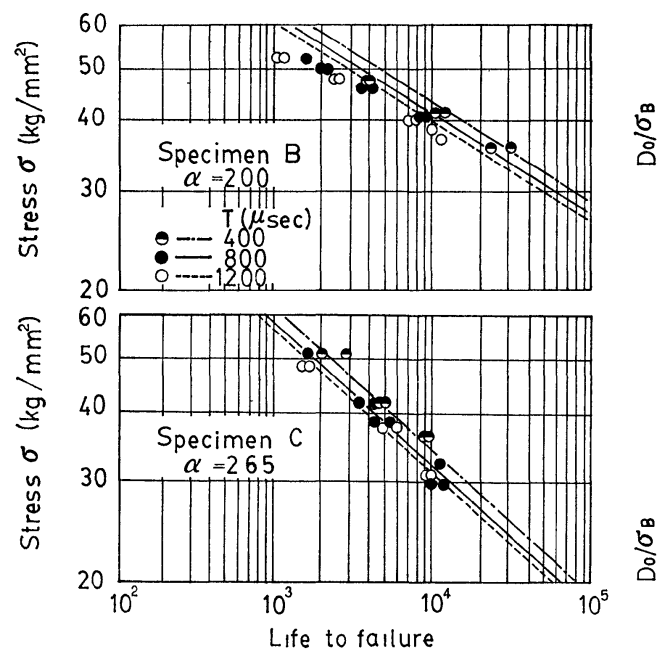

Fig. 16. Comparison between experimental and estimated values.

\section{4 結言}

本研究では， $0.2 \%$ 炭素鋼の平滑材および 4 種類の 環状切欠き材に対して繰返し衝撃引張荷重による低サ イクル疲労試験を行い平滑材と切欠き材との間に和け
る衝撃疲学強度の関連性あるいは切欠き効果の特徴に ついて究明した. 得られた結果は下記のとおりである.

(1) $0.2 \%$ 炭素鋼の衝撃疲労強度は, 平滑材の場合, 次式で近似でき,

$$
\sigma\left(N_{f} T\right)^{m_{0}}=D_{0}
$$

切欠き材の場合, 次式で近似できる.

$$
\sigma N_{f} m * T^{n *}=D^{*}
$$

（2）切欠き材の衝撃疲学強度の近似式に和ける指数 $m^{*}, n^{*}$ はいずれも, 切欠き部の応力集中が大きくな るほど, 増大する傾向があり, 応力集中係数 $\alpha$ と次式 のよらな関係がある. $\alpha \rightarrow 1$ のとき, $m^{*}, n^{*}$ の值は

$$
m^{*}=m_{0} \alpha^{a}, n^{*}=m_{0} \alpha^{b}
$$

いずれも, 平滑材の場合の指数 $m_{0}$ に等しくなる.

（3）切欠き材の場合の強度定数 $D^{*}$ は, 平滑材の場 合の強度定数 $D^{*}$ との間に次式のような関係があり, $\alpha \rightarrow 1$ のとき, $D^{*}$ は $D_{0}$ に等しくなる.

$$
D^{*}=D_{0} \alpha^{c} \exp m_{0}\left(\alpha^{b}-1\right) \ln T
$$

（4）切欠き材の衝撃疲労強度は, 低寿命領域では平 滑材より高応力レベルにあるが, 高寿命領域に移るに 従って応力集中の大きい切欠き材から順次, 平滑材の 衝撃疲労強度と逆転して行く.

（5）切欠き材の衝撃疲労に扣ける切欠き係数 $\beta$ は切 欠き部の応力集中係数 $\alpha$ および破壊寿命 $N_{f}$ の関数亡 して次式のように与えられる.

$$
\beta=\alpha^{-c} \exp m_{0}\left(\alpha^{a}-1\right) \ln N_{f}
$$

（6）引張強さが $\sigma_{B} \leqq 70 \mathrm{~kg} / \mathrm{mm}^{2}$ の鋼材の場合, そ の切欠き部材の衝撃疲労強度は, その鋼材の引張強さ $\sigma_{B}$ および破断絞り $\varphi$ を基に, 推定可能であると考兄 られよう。

（昭和51年 5 月 20 日 日本材料学会第25期総会学術講演会にて講演）

\section{参 考 文 献}

1）茶谷明義, 中沢 一, 中原一郎, 日本機械学会誌, 73, 1508 (1970).

2）秋園幸一，安宅 健，材料， 21，660 (1972).

3) 有井 満, 内田 猛, 岡部永年, 日本機械学会講演論文 集, No.730-12, 193 (1973).

4) 井口 宏, 日本材料学会第25期総会学術講演会前刷, 27 (1976).

5) 田中道七，中山英明，材料， 23，678 (1974).

6）西田正孝, 応力集中, 105 (1971) 森北出版

7) Tetelman, A. S., and A. J. McEvily, "Fracture of Structural, Materials”, 1, 278 (1970).

8）村木潤次郎, 石黒隆義, 半沢 貢, 片屋信彦, 学振第 129委員会 1 分科会資料 (1966). 